\title{
STRATEGI KOMUNIKASI PEMASARAN IKAN TERI (STOLEPHORUS SP.) KERING
}

\author{
Cawalinya Livsanthi Hasyim ${ }^{1}$, Elisabeth Cory Ohoiwutun ${ }^{2}$ \\ ${ }^{1,2}$ Politeknik Perikanan Negeri Tual \\ Jl. Raya Langgur - Sathean Km. 6, Kabupaten Maluku Tenggara, 97611, Indonesia \\ No. Telp./HP: ${ }^{1} 081242092142,{ }^{2} 081282026907$ \\ E-mail: ${ }^{1}$ cawalinya_84@yahoo.com, ${ }^{2}$ elisabeth_c_ohoiwutun@yahoo.com
}

\begin{abstract}
Naskah diterima tanggal 25 Januari 2018, direvisi tanggal 6 Juni 2018, disetujui tanggal 20 Agustus 2018
\section{MARKETING COMMUNICATION STRATEGY OF DRIED ANCHOVY (STOLEPHORUS SP.)}

\begin{abstract}
Marketing communication is an important thing that must be considered because it is one of the success or failure determinants factors of a business. The objective of this research is to arrange a marketing communication strategy that occured in the marketing of dried anchovy in Southeast Maluku Regency. The research method is qualitative descriptive and data analysis using Strengths, Weakness, Opportunities, Threats (SWOT) analysis. The research result show marketing strategy of dried anchovy in Southeast Maluku Regency was good because of good communication between dried anchovy trader with the customer and the communication that occurs by mouth to mouth communication. One of the advantages of the marketing communication conditions is that the marketing of dried anchovy is not only done in Southeast Maluku Regency but also done outside the area of Southeast Maluku Regency. Based on these conditions, the marketing communication strategy that has been done can be maintained to increase the opportunities. Also, it can be implemented other marketing communication strategies such as technology usages (promotion via local television, radio, Facebook, Twitter, etc.) while keeping the quality of dried anchovy.
\end{abstract}

Keywords: dried anchovy (stolephorus sp.), marketing communications, promotion, strategy.

\begin{abstract}
Abstrak. Komunikasi pemasaran merupakan hal penting yang harus diperhatikan karena merupakan salah satu faktor penentu berhasil tidaknya suatu usaha. Studi ini dilakukan untuk menyusun strategi komunikasi pemasaran yang terjadi pada pemasaran ikan teri kering di Kabupaten Maluku Tenggara. Metode penelitian yang digunakan pada penelitian ini adalah deskriptif kualitatif dan analisis data menggunakan analisis Strengths, Weakness, Opportunities, Threats (SWOT). Hasil penelitian menunjukkan, strategi komunikasi pemasaran ikan teri kering di Kabupaten Maluku Tenggara dapat dikatakan sudah baik dengan adanya komunikasi yang baik antara pedagang ikan teri kering dengan pelanggan yang terjadi melalui komunikasi dari mulut ke mulut. Salah satu kelebihan dari kondisi komunikasi pemasaran yang terjadi yaitu saat ini pemasaran ikan teri kering bukan saja dilakukan di Kabupaten Maluku Tenggara tetapi sudah dilakukan diluar daerah Kabupaten Maluku Tenggara. Berdasarkan kondisi tersebut maka strategi komunikasi pemasaran yang sudah dilakukan dapat dipertahankan untuk lebih meningkatkan peluang. Selain itu dapat menerapkan strategi komunikasi pemasaran lainnya seperti penggunaan teknologi (promosi melalui televisi lokal, radio, Facebook, Twitter dan lain-lain) dan tetap mengutamakan kualitas ikan teri kering.
\end{abstract}

Kata kunci: ikan teri (stolephorus sp.) kering, komunikasi pemasaraan, promosi, strategi. 


\section{PENDAHULUAN}

Ikan teri (Stolephorus sp.) merupakan salah salah satu sumber daya hayati laut yang tersedia hampir di seluruh wilayah Indonesia dan merupakan salah satu komoditas ekspor andalan di sektor perikanan. Dari sekian banyak komoditi hasil perikanan, ikan teri merupakan salah satu komoditas yang memiliki potensi besar dalam memberikan kontribusi terhadap perekonomian masyarakat.

Kabupaten Maluku Tenggara merupakan wilayah pengelolaan perikanan yang memiliki potensi yang sangat besar untuk dikembangkan. Produksi perikanan Kabupaten Maluku Tenggara diperoleh dari komoditi-komoditi perikanan salah satunya adalah ikan pelagis kecil yakni ikan teri (Stolephorus sp.) yang dikeringkan dan merupakan salah satu produk perikanan yang cukup menghasilkan dalam peningkatan ekonomi keluarga.

Salah satu dari jenis olahan ikan teri adalah ikan teri kering. Diversifikasi ikan teri menjadi ikan teri olahan dalam bentuk kering merupakan usaha yang relatif lama dan telah berkembang di Kabupaten Maluku Tenggara. Untuk pengembangan usaha ikan teri kering di Kabupaten Maluku Tenggara, maka dibutuhkan unsur pendukung dalam wujud ketersediaan informasi kondisi internal dan eksternal.

Namun diketahui bahwa dengan potensi yang ada ternyata belum mendapat dukungan yang baik dari pemerintah daerah setempat khususnya pada masalah pemasaran. Pemasaran ikan teri kering yang terjadi saat ini merupakan usaha yang dilakukan langsung dari pedagang ikan teri kering. Kondisi internal salah satunya yaitu pemasaran dan distribusi. Faktor eksternal salah satunya yaitu pelanggan dan pesaing yang memengaruhi perkembangan usaha.

Perkembangan dalam dunia bisnis, khususnya di bidang perikanan yaitu ikan teri kering, membuat persaingan antar pelaku bisnis juga semakin ketat. Hal ini menjadi tantangan bagi para pelaku bisnis agar dapat menghasilkan ikan teri kering yang kualitasnya baik serta dapat melakukan komunikasi pemasaran agar bisnis mereka dapat terus berlanjut.

Faktor penting yang memengaruhi pengembangan yaitu pemasaran dan distribusi, dan ini terkait dengan komunikasi pemasaran. Komunikasi pemasaran sangat berpengaruh pada tingkat penjualan suatu produk atau jasa, pendapat tersebut didukung oleh Kotler dan Amstrong (2008), yang berpendapat bahwa pemasaran adalah proses sosial dan manajerial antara pribadi atau organisasi memperoleh apa yang mereka butuhkan dan inginkan melalui penciptaan dan pertukaran nilai dengan yang lain.

Komunikasi pemasaran merupakan hal penting yang harus diperhatikan karena merupakan salah satu faktor penentu berhasil tidaknya pemasaran, sehingga perlu ditinjau lebih lanjut untuk menentukan strategi apa yang perlu dilakukan untuk mendukung pemasaran yang dilakukan oleh pengolah ikan teri kering di Kabupaten Maluku Tenggara.

\section{LANDASAN KONSEP}

\section{Ikan Teri (Stolephorus sp.) Kering}

Proses pembuatan ikan teri kering yaitu dengan proses pengeringan. Proses pengolahan diawali dengan pembersihan teri yang diterima dari para nelayan. Ikan teri yang sudah membusuk sebaiknya tidak ikut diolah. Ikan teri dicuci dengan air dingin untuk menghilangkan kotoran-kotoran yang tercampur dengan ikan, menghilangkan darah dan lendir. Isi perut dan insang ikan teri yang dicuci tidak perlu dibuang. Ikan teri dibersihkan dengan air bersih yang kemudian direbus dalam air mendidih. Ikan teri tersebut kemudian dikeringkan dengan cara dijemur di bawah sinar matahari secara langsung (Sedjati, 2006).

Menurut Hutomo dalam Susianawati (2006), ikan teri yang sudah diolah ini perlu dijaga dari kontaminasi jamur jika tidak sempurna keringnya, karena hal ini bisa membuat warna ikan teri tidak bersih (kecokelatan). Ikan teri yang kering dilakukan proses sorting, yaitu pemisahan teri dari kotoran dan jenis ikan lain yang ikut tersaring dalam jaring nelayan. Proses pemisahan ikan teri berdasarkan ukuran panjangnya (sizing), 
kemudian ikan teri tersebut dikemas dan siap didistribusikan.

\section{Komunikasi Pemasaran}

Terence A. Shimp (2014) mendefinisikan komunikasi pemasaran adalah aspek penting dalam keseluruhan misi pemasaran serta penentu suksesnya pemasaran. Komunikasi pemasaran juga dapat dipahami dengan menguraikan dua unsur pokoknya, yaitu komunikasi dan pemasaran. Komunikasi adalah proses pemikiran dan pemahaman yang disampaikan antar individu atau antara organisasi dengan individu, sementara pemasaran adalah sekumpulan kegiatan ketika perusahaan dan organisasi lainnya mentransfer nilai-nilai (pertukaran) antara mereka dengan pelanggannya.

Komunikasi pemasaran adalah kegiatan komunikasi yang dilakukan oleh pembeli dan penjual. Selain itu juga merupakan kegiatan yang membantu dalam pengambilan keputusan di bidang pemasaran serta mengarahkan pertukaran agar lebih memuaskan dengan cara menyadarkan semua pihak untuk berbuat lebih baik.

\section{Bauran Promosi}

Bauran promosi merupakan alat komunikasi yang terdiri dari kombinasi alatalat promosi yang digunakan oleh perusahaan. Pada umumnya alat-alat promosi tersebut memiliki hubungan yang erat, sehingga di antaranya tidak dapat dipisahkan, karena bersifat saling mendukung dan melengkapi.

Kotler \& Amstrong (2008) mengemukakan bahwa, "Promotion mix (marketing communications mix) is the specific blend of promotion tools that the company uses to persuasively communicate customer value and build customer relationships", yang artinya bauran promosi (bauran komunikasi pemasaran) adalah campuran spesifik dari alat-alat promosi yang digunakan perusahaan untuk secara persuasif mengomunikasikan nilai pelanggan dan membangun hubungan pelanggan. Menurut Kotler \& Amstrong (2008), bauran promosi terdiri atas 5 (lima) alat-alat promosi, yaitu:

1. Advertising (periklanan), yaitu semua bentuk presentasi dan promosi non personal yang dibayar oleh sponsor untuk mempresentasikan gagasan, barang atau jasa. Periklanan dianggap sebagai manajemen citra yang bertujuan menciptakan dan memelihara cipta dan makna dalam benak konsumen. Bentuk promosi yang digunakan mencakup broadcast, print, internet, outdoor, dan bentuk lainnya.

2. Sales promotion (promosi penjualan), yaitu insentif-insentif jangka pendek untuk mendorong pembelian atau penjualan suatu produk atau jasa. Bentuk promosi yang digunakan mencakup discounts, coupons, displays, demonstrations, contests, sweepstakes, dan events.

3. Personal selling (penjualan perseorangan), yaitu presentasi personal oleh tenaga penjualan dengan tujuan menghasilkan penjualan dan membangun hubungan dengan konsumen. Bentuk promosi yang digunakan mencakup presentations, trade shows, dan incentive programs.

4. Public relations (hubungan masyarakat), yaitu membangun hubungan yang baik dengan berbagai publik perusahaan supaya memperoleh publisitas yang menguntungkan, membangun citra perusahaan yang bagus, dan menangani atau meluruskan rumor, cerita, serta event yang tidak menguntungkan. Bentuk promosi yang digunakan mencakup press releases, sponsorships, special events, dan web pages.

5. Direct marketing (penjualan langsung), yaitu hubungan langsung dengan sasaran konsumen dengan tujuan untuk memperoleh tanggapan segera dan membina hubungan yang abadi dengan konsumen. Bentuk promosi yang digunakan mencakup catalogs, telephone marketing, kiosks, internet, mobile marketing, dan lainnya.

\section{Bauran Komunikasi Pemasaran}

Bauran komunikasi pemasaran (marketing communication mix) terdiri dari delapan model komunikasi utama (Keller \& Kotler, 2008), yaitu:

1. Periklanan, setiap bentuk presentasi non personal berbayar dan promosi gagasan, barang, atau jasa oleh sponsor diidentifikasi melalui media cetak (koran 
dan majalah), media penyiaran (radio dan televisi), media jaringan (telepon, kabel, satelit, wireless), media elektronik (rekaman suara, rekaman video, CDROM, halaman web), dan media tampilan (billboard, tanda-tanda, poster).

2. Promosi penjualan, berbagai insentif jangka pendek untuk mendorong percobaan atau pembelian produk atau jasa termasuk promosi konsumen (seperti sampel, kupon, dan premi), promosi perdagangan (seperti iklan dan display tunjangan), bisnis dan tenaga penjualan promosi (kontes untuk tenaga penjualan).

3. Events dan experiences, perusahaan yang mensponsori program yang dirancang untuk menciptakan interaksi harian atau merek terkait khusus dengan konsumen, termasuk olahraga, seni, hiburan, dan karena sebaiknya acara lebih sedikit kegiatan formal.

4. Humas dan publisitas, berbagai program diarahkan secara internal kepada karyawan dari perusahaan atau eksternal kepada konsumen, perusahaan lain, pemerintah, dan media untuk mempromosikan atau melindungi citra perusahaan atau produk komunikasi individu.

5. Direct marketing, penggunaan mail, telepon, e-mail, atau internet untuk berkomunikasi secara langsung dengan atau meminta respon atau dialog dari pelanggan tertentu dan prospek.

6. Interaktif marketing, online, dan program yang dirancang untuk melibatkan pelanggan atau prospek dan langsung atau tidak langsung meningkatkan kesadaran, meningkatkan citra, atau menimbulkan penjualan produk dan jasa.

7. Word of-mouth marketing, dari orang ke orang, tertulis, atau komunikasi elektronik yang berhubungan dengan manfaat atau pengalaman membeli atau menggunakan produk atau jasa.

8. Personal selling, interaksi secara langsung dengan satu atau lebih calon pembeli untuk tujuan membuat presentasi, menjawab pertanyaan, dan pengadaan pesanan.

\section{Manajemen Strategi}

Manajemen strategi sebagai suatu konsep yang terkait dengan faktor waktu melibatkan suatu proses yang kontinu dan iteratif dalam mencapai tujuan yang sesuai dengan kondisi lingkungan yang dihadapinya. Oleh karena itu, manajemen strategi dapat digunakan untuk mengidentifikasi kegiatan yang menjanjikan dan berfokus pada sumber daya (alam, manusia, dan buatan) untuk pengembangan jangka panjang serta menguntungkan (Hubeis \& Najib, 2008).

Suatu usaha dapat mengembangkan strategi untuk mengatasi ancaman eksternal dan merebut peluang yang ada. Proses analisis, perumusan, dan evaluasi strategistrategi itu disebut perencanaan strategi. Tujuan utama perencanaan strategi (renstra) adalah agar pihak-pihak terkait (pedagang ikan teri kering dan konsumen) dapat melihat secara objektif kondisi-kondisi internal dan eksternal, sehingga dapat mengantisipasi perubahan lingkungan eksternal. Dalam hal ini dapat dibedakan secara jelas, fungsi manajemen, konsumen, distributor, dan pesaing. Jadi perencanaan strategi penting untuk memperoleh keunggulan bersaing dan memiliki produk sesuai dengan keinginan konsumen dengan adanya dukungan optimal dari sumber daya yang ada (Rangkuti, 2004).

Strategi menjadi suatu kerangka fundamental tempat suatu usaha akan mampu menyatakan kontinuitasnya yang vital, sementara pada saat yang bersamaan akan memiliki kekuatan untuk menyesuaikan diri terhadap lingkungan yang selalu berubah (Purwanto, 2008). Salah satu yang diacu dalam Purwanto (2008) berpendapat bahwa strategi memiliki determinan-determinan umum terdiri dari komponen-komponen, yaitu: (1) tujuan dan sasaran; (2) lingkungan; (3) kemampuan internal; (4) kompetisi; (5) pembuat strategi; (6) komunikasi.

Para pengambil kebijakan strategi perlu menjamin strategi yang ditetapkan dapat berhasil dengan baik, bukan dalam tatanan konseptual, tetapi dapat dilaksanakan. Beberapa petunjuk mengenai cara pembuatan strategi (Purwanto, 2008), sehingga dapat berhasil, antara lain:

1. Strategi haruslah konsisten dengan lingkungannya.

2. Setiap strategi tidak hanya membuat satu strategi. 
3. Strategi yang efektif hendaknya memfokuskan dan menyatukan semua sumber daya dan tidak memisahkan satu dengan yang lainnya.

4. Strategi hendaknya memusatkan perhatian pada apa yang merupakan kekuatannya dan tidak pada titik-titik yang justru pada kelemahannya. Selain itu, hendaknya juga memanfaatkan kelemahan persaingan dan membuat langkah-langkah yang tepat untuk menempati posisi kompetitif yang lebih kuat.

5. Sumber daya adalah suatu yang kritis.

6. Strategi hendaknya dapat memperhitungkan risiko yang tidak terlalu besar.

7. Strategi hendaknya disusun di atas landasan keberhasilan yang telah dicapai.

8. Tanda-tanda dari suksesnya strategi ditampakkan dengan adanya dukungan dari pihak-pihak yang terkait, terutama dari para eksekutif, dari semua pimpinan unit kerja dalam usaha yang dilakukan.

Secara umum, tujuan melakukan analisis lingkungan adalah untuk menilai lingkungan secara keseluruhan. Lingkungan ini adalah faktor-faktor yang berada di luar, atau di dalam yang dapat memengaruhi kemajuan dalam mencapai tujuan yang telah ditetapkannya. Secara umum lingkungan dapat dikategorikan dalam dua bagian besar, yaitu lingkungan eksternal dan internal.

Lingkungan eksternal secara umum adalah lingkungan dalam lingkungan eksternal yang menyusun faktor-faktor yang memiliki ruang lingkup luas yang pada dasarnya berada di luar dan terlepas dari kegiatan operasi. Lingkungan ini hanya memiliki sedikit implikasi langsung bagi pengaturan. Faktorfaktor tersebut, antara lain faktor ekonomi, sosial dan teknologi.

Lingkungan internal adalah lingkungan yang berada dalam suatu usaha dan secara normal memiliki implikasi langsung dan khusus. Dengan demikian, analisis lingkungan internal mencakup analisis mengenai sumber daya, kapabilitas dan kompetensi yang dimiliki. Perlu mendapat perhatian serius manajemen untuk mampu menciptakan kapabilitas dan kompetensi inti yang sulit ditiru pesaing demi tercapainya keunggulan bersaing yang diinginkan (Hubeis \& Najib, 2008).

\section{Perumusan Strategi}

1. Matriks Internal Factor Evaluation (IFE) dan Matriks External Factor Evaluation (EFE). Matriks Internal Factor Evaluation (IFE) merupakan alat perumusan strategi dalam meringkas dan mengevaluasi kekuatan dan kelemahan utama dalam berbagai bidang fungsional dalam suatu usaha. Matriks ini juga menjadi landasan untuk mengidentifikasi dan mengevaluasi informasi terkait manajemen, pemasaran, keuangan, produksi, penelitian dan pengembangan serta operasi sistem informasi manajemen agroindustri (David, 2011). Menurut Pearce \& Robinson (2008), lingkungan internal agroindustri yaitu mencakup aspek organisasi, pemasaran, keuangan, personel (SDM), dan aspek produksi.

2. Matriks External Factor Evaluation (EFE) yaitu alat yang digunakan untuk membuat perencanaan strategi yang dapat meringkas dan mengevaluasi informasi ekonomi, sosial budaya, demografi, lingkungan, pemerintah, hukum, teknologi, dan persaingan (David, 2011). Lingkungan eksternal yang dapat dianalisis menurut Pearce \& Robinson (2008) mencakup persaingan, pemasok, konsumen, pemerintah dan peraturannya, komponen internasional, hukum, dan politik.

3. Matriks Internal-External (IE). Matriks IE berisi sembilan macam sel yang memperlihatkan kombinasi total nilai terboboti dari matriks IFE dan matriks EFE. Sembilan sel strategi pada matriks IE dapat dikelompokkan menjadi tiga sel strategi utama, yaitu: sel tumbuh dan bina atau berkembang (sel I, II, IV). Strategi yang mungkin tepat dikembangkan adalah strategi intensif meliputi penetrasi pasar, pengembangan produk, pengembangan pasar serta strategi integrasi ke depan, ke belakang, dan horizontal. Sel pertahankan dan pelihara (sel III, V, VII). Strategi yang mungkin tepat dikembangkan adalah strategi penetrasi pasar dan pengembangan produk. Sel panen atau divestasi (sel VI, VIII, IX). 


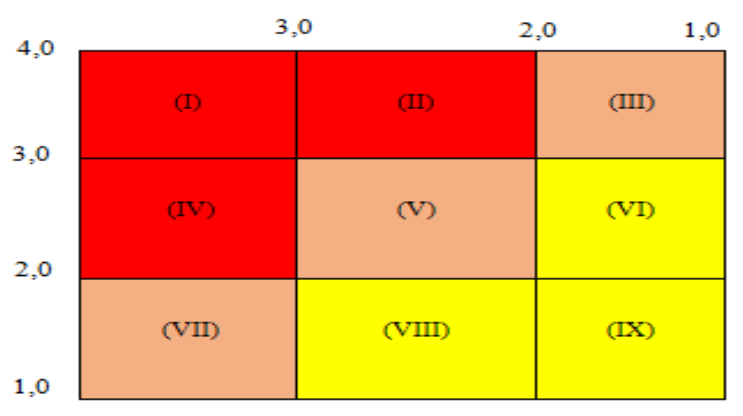

Sumber: Dwiastuti (2008).

Gambar 1. Sel Strategi Matriks IE

Keterangan:

\begin{tabular}{|c|}
\hline Tumbuh dan berkembang = Pengembangan pasar \\
\hline Pertahankan dan pelihara $=$ Penetrasi pasar, pengembangan produk \\
\hline Panen $=$ Menikmati hasil \\
\hline
\end{tabular}

Pada sumbu $\mathrm{x}$ matriks IE, total nilai IFE yang diberi bobot dari 1,00 sampai 1,99 menunjukkan posisi internal yang lemah, nilai 2,00 sampai 2,99 dianggap sedang, dan nilai 3,00 sampai 4,00 dianggap kuat. Begitu pula pada sumbu y, total nilai EFE yang diberi bobot 1,00 sampai 1,99 dianggap rendah, nilai 2,00 sampai 2,99 dianggap sedang, dan 3,00 sampai 4,00 dianggap tinggi (Dwiastuti, 2008). Berikut adalah Gambar dari sembilan sel strategi pada matriks IE.

Matriks Strengths, Weakness, Opportunities, Threats (SWOT)

Analisis SWOT adalah identifikasi berbagai faktor secara sistematis untuk merumuskan strategi agroindustri. Analisis ini didasarkan pada logika yang dapat memaksimalkan kekuatan (strength), dan peluang (opportunities), namun secara bersamaan dapat meminimalkan kelemahan (weakness) dan ancaman (threats). Proses pengembalian keputusan strategis selalu berkaitan dengan pengembangan misi, tujuan, strategi, dan kebijakan agroindustri. Sehingga perencana strategis harus menganalisis faktorfaktor strategis agroindustri yaitu kekuatan, kelemahan, peluang, dan ancaman dalam kondisi yang ada saat ini. Hal ini disebut dengan analisis situasi. Model yang paling populer untuk analisis situasi adalah analisis SWOT (Rangkuti, 2004) seperti ditunjukkan pada Tabel 1.

\section{Tabel 1}

Matriks SWOT

\begin{tabular}{|c|c|c|}
\hline IFE & $\begin{array}{c}\text { STRENGTH }(\mathbf{S}) \\
\text { Tentukan faktor-faktor } \\
\text { kekuatan internal }\end{array}$ & $\begin{array}{l}\text { WEAKNESSES }(\mathbf{W}) \\
\text { Tentukan faktor-faktor } \\
\text { kelemahan internal }\end{array}$ \\
\hline EFE & & \\
\hline $\begin{array}{l}\text { OPPORTUNITIES }(\mathbf{O}) \\
\text { Tentukan faktor peluang } \\
\text { eksternal }\end{array}$ & $\begin{array}{l}\text { STRATEGI (SO) } \\
\text { Menciptakan strategi } \\
\text { menggunakan kekuatan } \\
\text { untuk mendapatkan peluang }\end{array}$ & $\begin{array}{l}\text { STRATEGI (WO) } \\
\text { Menciptakan strategi yang } \\
\text { mengurangi kelemahan } \\
\text { untuk memanfaatkan } \\
\text { peluang }\end{array}$ \\
\hline $\begin{array}{l}\text { THREATS (T) } \\
\text { Tentukan faktor ancaman } \\
\text { eksternal }\end{array}$ & $\begin{array}{l}\text { STRATEGI (ST) } \\
\text { Menciptakan strategi yang } \\
\text { menggunakan kekuatan } \\
\text { untuk mengatasi ancaman }\end{array}$ & $\begin{array}{l}\text { STRATEGI (WT) } \\
\text { Menciptakan strategi yang } \\
\text { meminimalkan kelemahan } \\
\text { dan menghindari ancaman }\end{array}$ \\
\hline
\end{tabular}




\section{METODE PENELITIAN}

Penelitian ini dilakukan di Kabupaten Maluku Tenggara dikhususkan pada Desa Sathean, Selayar, dan Ohoililir, kepada konsumen dan pedagang pengumpul. Konsumen untuk ikan teri kering berlokasi di Kabupaten Maluku Tenggara dan Kota Tual. Untuk pedagang pengumpul berlokasi di Kabupaten Maluku Tenggara di tahun 2017.

Penentuan informan dalam penelitian ini dilakukan secara incidental sampling yakni prosedur sampling yang memilih sampel dari orang yang paling mudah dijumpai, sehingga siapapun yang ditemui peneliti pada saat melakukan penelitian di lokasi penelitian memenuhi syarat sebagai informan. Informan yang dipilih adalah yang berkompeten dalam memberikan informasi tentang komunikasi pemasaran ikan teri kering yang mereka lakukan.

Jumlah informan untuk nelayan ikan teri terdiri dari lima orang dari Desa Sathean, lima orang dari Desa Selayar, dan lima orang dari Ohoililir. Untuk konsumen lima orang dan pedagang pengumpul lima orang.

Penelitian ini menggunakan dua jenis sumber data yaitu data primer dan data sekunder. Data primer yang peneliti gunakan untuk mendapatkan jawaban atas permasalahan yang diajukan dalam penelitian ini. Data primer diperoleh dengan cara melakukan wawancara mendalam (indepth interview) terhadap informan dengan alat bantu pedoman wawancara. Data sekunder digunakan untuk memperkuat data primer, data sekunder dapat juga dijadikan sebagai data tambahan jika data primer dianggap belum memadai sejauh data primer tidak bisa lagi didapatkan. Data sekunder diperoleh dengan cara melakukan studi pustaka (library research) pada tesis, jurnal ilmiah, internet dan menggunakan informasiinformasi yang dihasilkan oleh instansi terkait dengan objek penelitian.

Analisis data dalam pendekatan kualitatif diperoleh dari hasil pengumpulan data dan informasi melalui observasi dan wawancara. Data dalam penelitian kualitatif ini berupa kata-kata, perilaku atau tindakan yang dapat di observasi. Teknik analisis data dalam penelitian ini menggunakan model interaksi, yang terdiri dari tiga hal utama yaitu: reduksi data, penyajian data, dan menarik simpulan. Analisis perumusan strategi yang melalui tahapan: (1) analisis matriks IFE-EFE; (2) analisis matriks IE; (3) dan analisis matriks SWOT.

\section{HASIL PENELITIAN DAN PEMBAHASAN}

\section{Sistem Pemasaran Ikan Teri Kering dan Pedagang Pengumpul (Tengkulak) Hingga ke Konsumen}

Komunikasi pemasaran merupakan aspek penting dalam keseluruhan misi pemasaran serta penentu suksesnya pemasaran. Oleh karena itu komunikasi pemasaran dapat diartikan sebagai sarana produsen untuk menginformasikan, membujuk, dan mengingatkan konsumen secara langsung maupun tidak langsung tentang produk yang dijual.

Pemasaran ikan teri kering selama ini berjalan sesuai dengan mekanisme pasar, yaitu penjualan ikan teri kering dari produsen ke konsumen akhir, penjualan dari produsen ke tengkulak setelah itu ke konsumen akhir. Berdasarkan hasil survei di lapangan menunjukkan bahwa pemasaran ikan teri kering sangat tergantung pada persediaan ikan teri basah yang kemudian diproses menjadi ikan teri kering. Kondisi ini disebabkan karena ikan teri tidak dapat ditangkap pada setiap musim atau setiap bulan, hanya pada bulan-bulan tertentu yaitu pada bulan Agustus, September, dan Oktober. Dengan demikian secara tidak langsung kondisi tersebut sangat berpengaruh terhadap jumlah permintaan terhadap ikan teri kering dan harga jual.

Ohoi Sathean, Ohoi Selayar, dan Ohoililir merupakan beberapa desa penghasil ikan teri kering di Kabupaten Maluku Tenggara. Berdasarkan hasil wawancara dengan nelayan yang menjadi informan pada ketiga desa tersebut menyatakan bahwa ikan teri kering dari desa-desa tersebut dipasarkan dengan dua (2) jalur yakni: 1) Dijual langsung oleh nelayan ke pasar atau langsung ke konsumen dan lokasi sekitar nelayan. 2) Dijual melalui pedagang pengumpul atau 
tengkulak. Memasarkan ikan teri kering secara langsung, baik untuk pasar lokal maupun untuk luar daerah. Dalam hal ini nelayan tersebut menjadi eksportir.

Alur pemasaran yang dilakukan nelayan dengan memasarkan ikan teri kering secara langsung ke pedagang pengumpul (tengkulak), kemudian pedagang pengumpul tersebut memasarkan ikan teri kering tersebut ke tingkat pedagang kecil hingga sampai pada konsumen akhir. Dalam sistem pemasaran ini, pedagang pengumpul juga mengirim produknya ke luar daerah. Berdasarkan hasil wawancara dengan pedagang pengumpul bahwa nelayan ikan teri kering memasarkan produk selain ikan teri kering juga memasarkan ikan teri basah pada pedagang pengumpul, yang nantinya akan diolah sendiri dengan mengeringkannya sendiri kemudian di jual kepada konsumen baik lokal maupun ke luar daerah.

Berdasarkan hasil survei dan wawancara dengan nelayan ikan teri kering di tiga desa penelitian, harga jual yang diberikan dalam penjualan langsung sama dengan harga jual yang diberikan kepada distributor. Menurut beberapa nelayan yang diwawancarai dari masing-masing desa lokasi penelitian, harga jual produk ikan teri kering yaitu Rp30.000/kg sampai dengan $\mathrm{Rp} 40.000 / \mathrm{kg}$ yang dipasarkan langsung ke konsumen maupun ke pedagang pengumpul (tengkulak). Selain itu ikan teri basah yang dijual ke pedagang pengumpul dengan harga Rp600.000/ember besar. Pedagang pengumpul (tengkulak) setelah membeli ikan teri dari kemudian memasarkan ikan teri kering tersebut baik ke konsumen lokal maupun ke konsumen di luar daerah seperti ke Timika, Surabaya, dan Bima dengan kisaran harga Rp50.000/kg.

Pemasaran yang efisien apabila penjualan produk dapat mendatangkan keuntungan yang tinggi bagi produsen. Hasil penelitian menunjukkan bahwa komunikasi pemasaran ikan teri kering di Kabupaten Maluku Tenggara dapat dikatakan cukup baik. Kondisi ini dapat diketahui dari konsumen maupun tengkulak yang membutuhkan ikan teri kering dapat memperoleh ikan teri kering dengan mudah dari produsen walaupun jumlahnya tidak menentu, selain itu pemasaran ikan teri kering yang dilakukan bukan saja bersifat lokal namun sudah sampai pada pasar di luar daerah yaitu Timika (Papua), Surabaya, dan Bima. Berdasarkan kondisi tersebut maka secara tidak langsung dapat dikatakan bahwa komunikasi pemasaran untuk ikan teri kering sudah terlaksana dengan baik.

Hasil penelitian menunjukkan bahwa upaya yang dilakukan oleh masyarakat nelayan dalam meningkatkan penjualan ikan teri kering selama ini dilakukan secara langsung dengan memperkenalkan produk ikan teri kering kepada pembeli dan menginformasikan tentang ikan teri kering tersebut kepada konsumen yang pada akhirnya konsumen tersebut menginformasikan kepada konsumen lainnya. Dengan demikian nelayan tersebut telah menerapkan bentuk-bentuk utama dari komunikasi pemasaran yakni penjualan perorangan (personal selling) dan komunikasi di tempat pembelian (purchase of communication) serta menerapkan konsep bauran pemasaran secara tidak langsung oleh nelayan usaha ikan teri kering. Alur pemasaran ikan teri kering tersebut dapat dilihat pada Gambar 2.

\section{Hambatan-hambatan dalam Komunikasi Pemasaran Ikan Teri Kering}

Secara umum, distribusi pemasaran produk ikan teri kering tidak terlalu mengalami kesulitan karena transportasi mudah didapatkan untuk memasarkan produk ikan teri kering ke pasar-pasar yang ada di Kabupaten Maluku Tenggara dan pedagang pengumpul (tengkulak) sendiri yang datang untuk mengambil produk ikan teri kering tersebut.

Berdasarkan kondisi di lapangan yaitu pada tiga lokasi penelitian yang terdiri dari desa Sathean, Selayar, dan Ohoililir terkait komunikasi pemasaran ikan teri kering masih dijumpai adanya masalah atau hambatan. Hambatan utama yang dihadapi pedagang ikan teri kering adalah kemampuan pedagang ikan teri kering dalam memenuhi jumlah pesanan dari konsumen. Hal ini disebabkan karena ikan teri hanya dapat diperoleh pada musim-musim tertentu, dengan demikian 
akan sangat berpengaruh pada tersedianya jumlah ikan teri kering.

Hambatan lainnya, pada aspek teknologi komunikasi seperti terbatasnya fasilitas komunikasi atau fasilitas komunikasi yang kurang memadai untuk melakukan promosi dengan penggunaan teknologi komunikasi. Berdasarkan hasil pengamatan dan wawancara dengan nelayan mengatakan bahwa fasilitas komunikasi yang digunakan untuk memasarkan ikan teri kering adalah menggunakan telepon seluler. Selain itu, berdasarkan hasil wawancara dengan beberapa nelayan yakni keadaan cuaca yang buruk sehingga pengeringan ikan bisa memakan waktu yang cukup lama, dan harga ikan teri kering yang tidak menentu.

\section{Strategi Komunikasi Pemasaran Ikan Teri Kering}

Untuk melakukan suatu usaha harus menggunakan strategi yang dapat dilakukan dalam memperkenalkan produk. Strategi komunikasi pemasaran yang dapat diterapkan oleh nelayan ikan teri kering tersebut antara lain:

1. Promosi langsung yaitu penjualan langsung secara tatap muka dan melalui mulut ke mulut (word of mouth) dan penjualan ditempat (point of purchase communication).

2. Product element, kualitas dari produk ikan teri kering menjadi pertimbangan konsumen dalam mengonsumsi produk tersebut.

3. Promosi dan edukasi, antara lain: membuat brosur dan menyebarkannya. Selain di kabupaten, dapat disebarkan di Kota Tual dan luar daerah sehingga konsumen mengetahui dengan jelas lokasi penjualan dan kualitas dari ikan teri kering tersebut.

4. Promosi melalui media elektronik yakni melalui TV lokal dan RRI Tual.

5. Pengguna internet semakin hari semakin meningkat, sehingga kegiatan promosi melalui media internet bisa menjadi sangat efektif. Produsen dan tengkulak atau pedagang pengumpul dapat membuat media online seperti media sosial (Facebook, Twitter, WhatsApp), dan website untuk mempromosikan produk ikan teri kering.

Rancangan strategi komunikasi pemasaran ikan teri kering tersebut dapat dilihat pada Gambar 3.

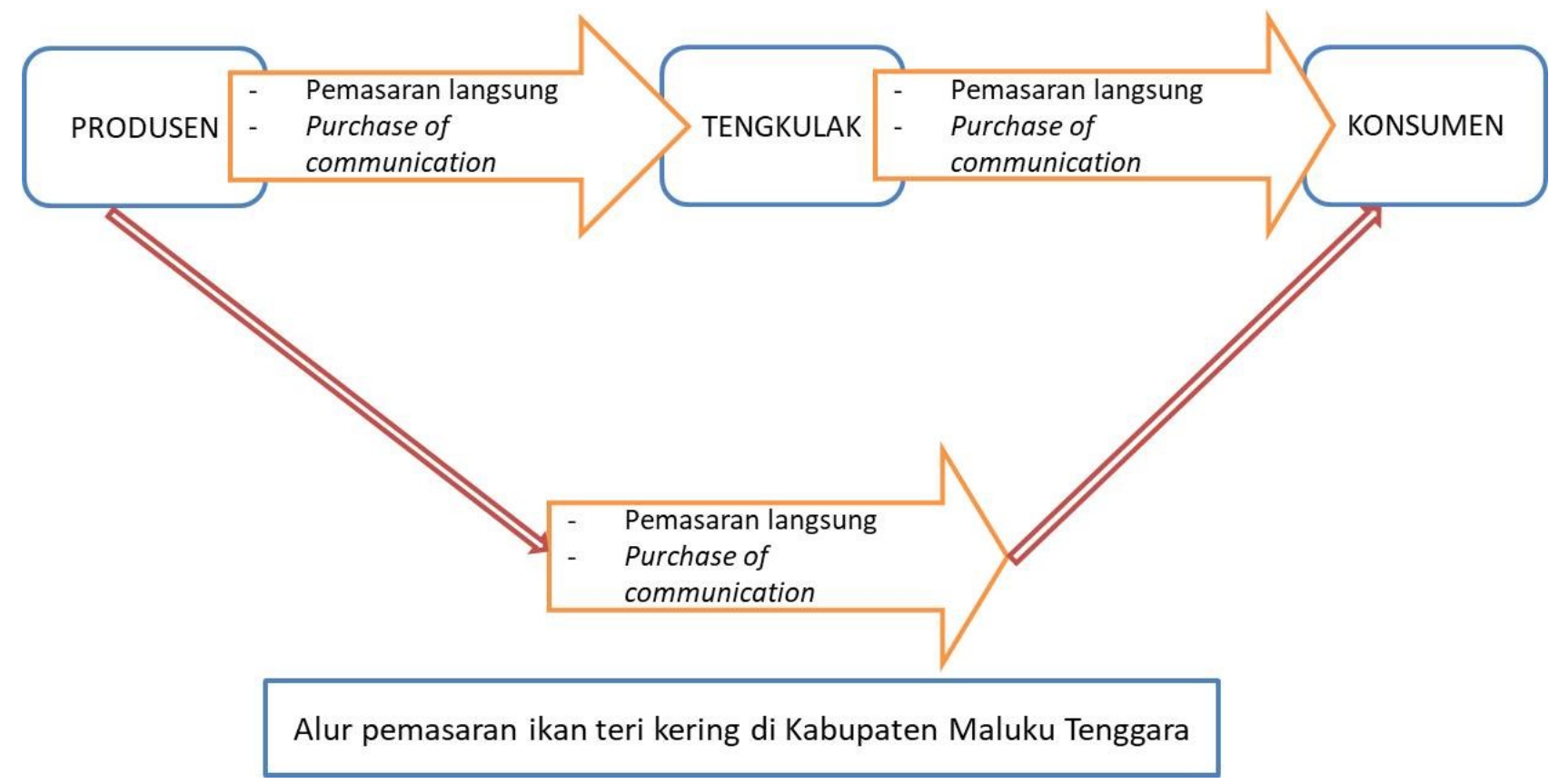

Gambar 2. Alur Pemasaran Ikan Teri Kering di Kabupaten Maluku Tenggara 


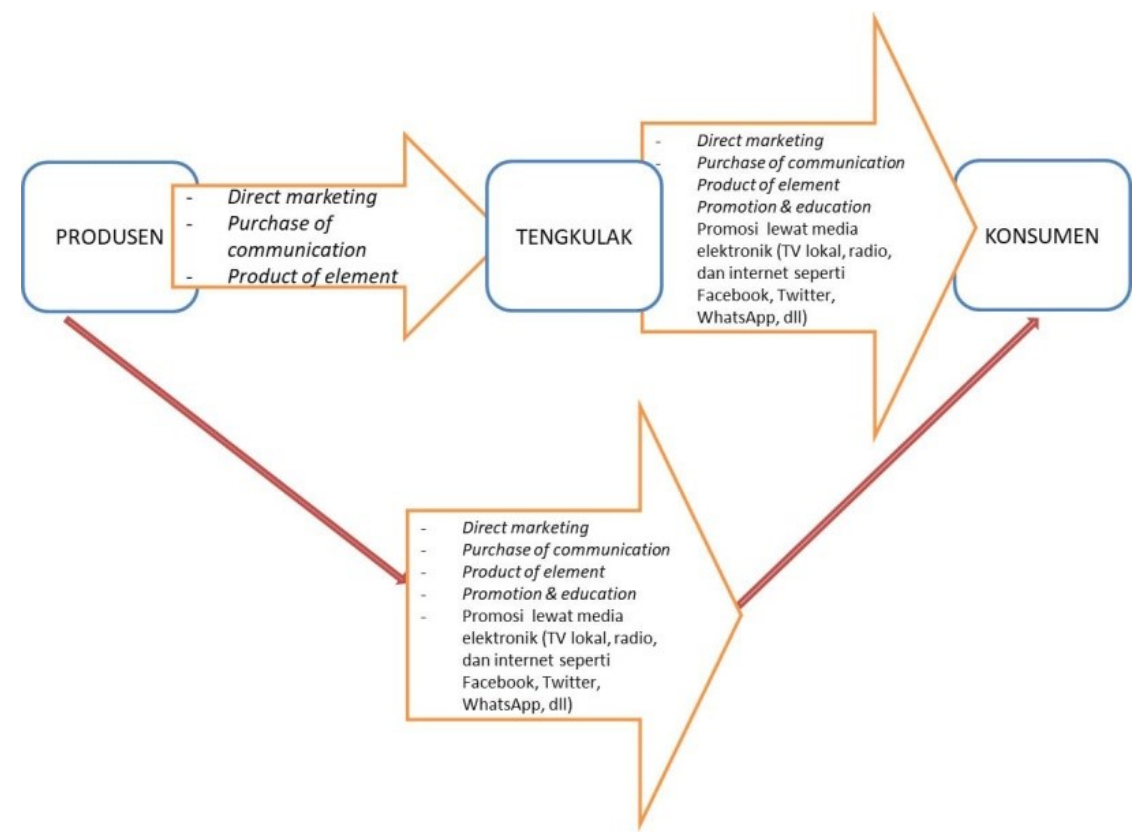

Gambar 3. Strategi Komunikasi Pemasaran Ikan Teri Kering di Kabupaten Maluku Tenggara

Berdasarkan hasil wawancara, nelayan menggunakan alat komunikasi dalam melakukan pemasaran yaitu telepon seluler namun sebatas SMS, untuk penjualan dilakukan tatap muka dengan memperlihatkan kualitas produk ikan teri kering. Pada promosi ikan teri kering, nelayan dapat menerapkan strategi komunikasi pemasaran untuk jangka panjang yaitu dengan menjaga hubungan baik dengan pedagang pengumpul (tengkulak) maupun dengan konsumen. Nelayan dapat menerapkan strategi komunikasi pemasaran untuk jangka panjangnya yakni dengan senantiasa menjaga hubungan baik dengan para konsumen, agar loyalitasnya semakin tinggi terhadap produk ikan teri kering, hal ini dilakukan untuk meminimalisir konsumen berpindah ke produsen kecil lainnya.

Sedangkan untuk strategi komunikasi pemasaran yang dapat diterapkan oleh nelayan untuk jangka pendek adalah memberikan kesan positif dimulai dari cara berkomunikasi dengan baik kepada konsumen maupun kepada tengkulak dengan mengemukakan kualitas produk ikan teri kering, sehingga konsumen pun merasa nyaman atas pelayanan yang telah diberikan tentang produk ikan teri kering yang dihasilkan dan diharapkan konsumen dapat tertarik serta tidak ada lagi keraguan untuk mengonsumsi ikan teri kering.

Berdasarkan penjelasan tersebut maka strategi komunikasi pemasaran yang dilakukan untuk jangka pendeknya adalah 140 dengan memberikan kesan positif dimulai dari cara berkomunikasi yang baik kepada konsumen sehingga konsumen pun merasa puas atas pelayanan yang telah diberikan. Dari penjelasan tersebut dapat diketahui bahwa teknik pemasaran yang dilakukan untuk konsumen yang berada di dalam maupun di luar daerah pada prinsipnya sama yaitu memberikan layanan yang terbaik. Namun yang membedakannya adalah faktor biaya produksi, waktu, dan jarak.

\section{Analisis Matriks IFE}

Faktor-faktor untuk menyusun matriks IFE adalah faktor-faktor internal yang terdiri dari kekuatan dan kelemahan. Hasil analisis matriks IFE dapat dilihat pada Tabel 2.

Berdasarkan hasil perhitungan matriks IFE pada Tabel 2, dapat dilihat bahwa faktor kekuatan yang menduduki peringkat pertama dengan nilai tertimbang 0,548 adalah adanya komunikasi yang baik antara produsen dan konsumen. Hasil hitungan matriks IFE menunjukkan bahwa komunikasi merupakan salah satu faktor utama yang harus diperhatikan dalam melakukan pemasaran suatu produk dan sesuai dengan teori yang menyatakan bahwa pemasaran adalah proses sosial dan manajerial dimana pribadi atau organisasi memperoleh apa yang mereka butuhkan dan inginkan melalui penciptaan dan pertukaran nilai dengan yang lain. Faktor ini menjadi salah satu kekuatan yang sangat 
penting pada komunikasi pemasaran ikan teri kering di Kabupaten Maluku Tenggara.

Pada faktor kelemahan, proses pengeringan masih bersifat tradisional memiliki nilai tertimbang tertinggi, yaitu 0,202. Proses pengeringan masih bersifat tradisional sangat berpengaruh dalam usaha perikanan ikan teri kering yang dilakukan, karena secara langsung akan memengaruhi proses penjualan ikan teri kering. Bobot skor total diperoleh adalah 2,803. Hal ini menunjukkan bahwa komunikasi pemasaran ikan teri kering di Kabupaten Maluku Tenggara memiliki posisi internal yang sedang.

\section{Analisis Matriks EFE}

Matriks EFE berguna untuk mengetahui seberapa besar faktor-faktor eksternal yang memengaruhi komunikasi pemasaran ikan teri kering di Kabupaten Maluku Tenggara. Faktor eksternal terdiri dari peluang dan ancaman. Hasil analisis matriks EFE dapat dilihat pada Tabel 3. Berdasarkan hasil perhitungan matriks EFE pada Tabel 3, dapat dilihat bahwa faktor peluang yang menduduki peringkat pertama dengan nilai tertimbang 0,56 adalah pemasaran dilakukan pada pasar lokal dan pasar di luar daerah. Hasil hitungan pada matriks EFE sesuai dengan kondisi yang ada yaitu pemasaran ikan teri kering dilakukan di Kabupaten Maluku Tenggara, Kota Tual, Timika Papua, Bima, dan Surabaya.

Tabel 2

Hasil Analisis Matriks IFE

\begin{tabular}{lccc}
\hline \multicolumn{1}{c}{ Faktor Internal } & $\begin{array}{c}\text { Bobot } \\
(\mathbf{A})\end{array}$ & $\begin{array}{c}\text { Rating } \\
(\mathbf{B})\end{array}$ & $\begin{array}{c}\text { Skor } \\
(\mathbf{A x B})\end{array}$ \\
\hline Kekuatan & & & \\
Adanya komunikasi yang baik antara produsen dan konsumen & 0,137 & 4 & 0,548 \\
Produk ikan teri kering dapat bertahan lama & 0,113 & 4 & 0,452 \\
Produk ikan teri kering banyak disukai oleh konsumen & 0,128 & 4 & 0,512 \\
Pedagang ikan teri kering memiliki motivasi yang tinggi & 0,104 & 4 & 0,417 \\
Kelemahan & & & \\
Jumlah ikan teri kering yang dihasilkan tidak menentu & 0,098 & 2 & 0,229 \\
Proses pengeringan masih bersifat tradisional & 0,152 & 1 & 0,202 \\
Belum adanya arsip pembukuan & 0,131 & 2 & 0,306 \\
Kegiatan promosi belum memanfaatkan media yang ada & 0,137 & 1 & 0,137 \\
TOTAL & 1.000 & 23 & 2.803 \\
\hline
\end{tabular}

Sumber: Olahan Data Penulis Berdasarkan Hasil Wawancara

Tabel 3

Hasil Analisis Matriks EFE

\begin{tabular}{lccc}
\hline \multicolumn{1}{c}{ Faktor Eksternal } & $\begin{array}{c}\text { Bobot } \\
(\mathbf{A})\end{array}$ & $\begin{array}{c}\text { Rating } \\
(\mathbf{B})\end{array}$ & $\begin{array}{c}\text { Skor } \\
(\mathbf{A x B})\end{array}$ \\
\hline Peluang & & & \\
Pemasaran dilakukan pada pasar lokal dan pasar di luar daerah & 0.140 & 4 & 0.56 \\
Harga jual ikan teri kering tinggi & 0.128 & 4 & 0.512 \\
Jumlah permintan atau pesanan banyak & 0.110 & 4 & 0.44 \\
Adanya loyalitas pelanggan & 0.131 & 4 & 0.524 \\
Ancaman & & & \\
Belum adanya kerjasama dengan pemerintah untuk pemasaran produk ikan teri kering & 0.119 & 1 & 0.159 \\
Fluktuasi harga penjualan & 0.125 & 2 & 0.208 \\
Persedian bahan baku berdasarkan musim & 0.128 & 1 & 0.128 \\
Belum memiliki kemasan untuk produk & 0.119 & 2 & 0.238 \\
TOTAL & 1.000 & 22 & 2.769 \\
\hline
\end{tabular}

Sumber: Olahan Data Penulis Berdasarkan Hasil Wawancara 
Faktor ini menjadi salah satu peluang yang sangat penting dalam komunikasi pemasaran ikan teri kering di Kabupaten Maluku Tenggara. Hal ini juga didukung oleh faktor-faktor peluang lainnya, yang merupakan peluang cukup penting untuk diperhatikan.

Pada faktor ancaman, persediaan bahan baku berdasarkan musim memiliki nilai tertimbang tertinggi, yaitu 0,128 dan menjadi ancaman utama bagi usaha perikanan di Kabupaten Maluku Tenggara. Ancaman ini menjadi penghambat usaha perikanan khususnya para pedagang ikan teri kering di Kabupaten Maluku Tenggara. Hal ini menunjukkan bahwa faktor ini diharapkan segera dapat diatasi dan diharapkan adanya suatu strategi yang akan dilaksanakan untuk dapat segera mengatasi masalah tersebut. Bobot skor total pada faktor eksternal adalah 2,769. Hal ini menunjukkan bahwa komunikasi pemasaran ikan teri kering di Kabupaten Maluku Tenggara memiliki posisi eksternal yang sedang.

\section{Analisis Matriks IE}

Matriks IE merupakan matriks yang menggabungkan bobot skor pada Matriks IFE dan matriks EFE untuk melihat posisi sel usaha komunikasi pemasaran ikan teri kering. Jika posisi sel telah diketahui, maka diketahui pula strategi yang harus dilakukan oleh pemerintah daerah setempat dalam meningkatkan pendapatan nelayan. Dari perhitungan matriks IFE didapatkan bobot skor 2,803 dan dari matriks EFE didapatkan bobot skor 2,769. Hasil pemetaan matriks IE dapat dilihat pada Gambar 4.

Komunikasi pemasaran ikan teri kering di Kabupaten Maluku Tenggara menempati posisi sel V. Sel V ini menggambarkan bahwa posisi komunikasi pemasaran ikan teri kering di Kabupaten Maluku Tenggara berada pada posisi menjaga dan mempertahankan. Strategi yang tepat bagi usaha yang berada di sel ini adalah strategi penetrasi pasar dan strategi pengembangan produk (David, 2011).

\section{Analisis Matriks SWOT}

Analisis matriks IFE dan EFE yang telah dilakukan kemudian disusun dalam matriks SWOT untuk merumuskan strategi- strategi berdasarkan faktor-faktor internal dan eksternal yang telah teridentifikasi dari komunikasi pemasaran ikan teri kering di Kabupaten Maluku Tenggara. Perumusan strategi komunikasi pemasaran ikan teri kering di Kabupaten Maluku Tenggara dimuat pada Tabel 4. Perumusan strategi dengan matriks SWOT terdiri dari empat (4) kombinasi faktor, yang terdiri dari strategi Kekuatan-Peluang (SO), strategi Kekuatan-Ancaman (S-T), strategi Kelemahan-Peluang (W-O) dan strategi Kelemahan-Ancaman (W-T).

Berdasarkan Tabel 4, terdapat empat strategi yang dapat dirumuskan dari kombinasi faktor internal dan eksternal. Empat strategi ini dibagi menjadi empat kelompok strategi, yaitu:

1. Strategi S-O (Strenghts-Opportunities)

Strategi ini adalah strategi yang diciptakan atau dirumuskan dengan menggunakan kekuatan internal komunikasi pemasaran ikan teri kering untuk memanfaatkan peluang. Dengan meningkatkan hubungan kerja yang baik antara konsumen dan produsen dengan memanfaatkan potensi pemasaran yang telah dilakukan.

2. Strategi W-O (Weakness- Opportunities) Strategi ini bertujuan untuk meminimalkan, atau memperbaiki kelemahan internal dengan cara mengambil manfaat dari peluang eksternal. Dengan memanfaatkan peluang pemasaran ikan teri kering yang dilakukan pada pasar lokal dan pasar luar daerah dengan mengatasi proses pengeringan yang masih bersifat tradisional.

3. Strategi S-T (Strenghts- Threats)

Strategi ini diciptakan dengan menggunakan kekuatan pada komunikasi pemasaran ikan teri kering untuk menghindari, atau mengatasi dampak ancaman eksternal. Dengan memanfaatkan komunikasi yang baik antara konsumen dan produsen untuk mengatasi persediaan bahan baku yang berdasarkan musim.

4. Strategi W-T (Weakness- Threats)

Strategi ini diciptakan untuk
meminimalkan kelemahan dan
menghindari ancaman. Melakukan


inovasi terhadap proses pengeringan ikan teri kering yang masih bersifat tradisional untuk mengatasi persediaan bahan baku yang berdasarkan musim.

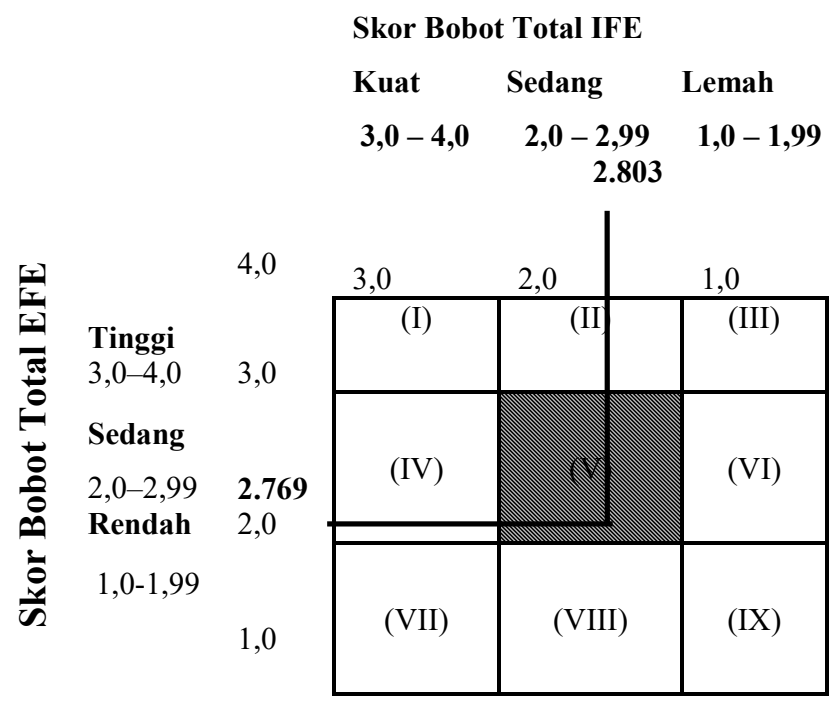

Sumber: Olahan Data Penulis Berdasarkan Hasil Wawancara

Gambar 4. Hasil Pemetaan Matriks IE

Tabel 4

Matriks SWOT komunikasi pemasaran ikan teri kering di Kabupaten Maluku Tenggara

\begin{tabular}{|c|c|c|}
\hline Faktor-faktor & Kekuatan (Strenghts-S) & Kelemahan (Weakness- $W$ ) \\
\hline $\begin{array}{l}\text { Faktor Eksternal } \\
\text { (External Factor) }\end{array}$ & $\begin{array}{l}\text { Adanya komunikasi yang } \\
\text { baik antara produsen dan } \\
\text { konsumen (S1) } \\
\text { Produk ikan teri kering } \\
\text { dapat bertahan lama (S2) } \\
\text { Produk ikan teri kering } \\
\text { banyak disukai oleh } \\
\text { konsumen (S3) } \\
\text { Pedagang ikan teri kering } \\
\text { meiliki motivasi yang } \\
\text { tinggi (s4) }\end{array}$ & $\begin{array}{l}\text { Jumlah ikan teri kering yang } \\
\text { dihasilkan tidak menentu } \\
\text { (W1) } \\
\text { Proses pengeringan masih } \\
\text { bersifat tradisional (W2) } \\
\text { Belum adanya arsip } \\
\text { pembukuan (W3) } \\
\text { Kegiatan promosi belum } \\
\text { memanfaatkan media yang } \\
\text { ada (W4) }\end{array}$ \\
\hline $\begin{array}{l}\text { Peluang (Opportunities-O) } \\
\text { Pemasaran dilakukan pada pasar } \\
\text { lokal dan pasar di luar daerah } \\
\text { (O1) } \\
\text { Harga jual ikan teri kering tinggi } \\
\text { (O2) } \\
\text { Jumlah permintaan atau pesanan } \\
\text { banyak (O3) } \\
\text { Adanya loyalitas pelanggan } \\
(\mathrm{O} 4)\end{array}$ & $\begin{array}{l}\text { Meningkatkan hubungan } \\
\text { kerja yang baik antara } \\
\text { konsumen dan produsen } \\
\text { dengan memanfaatkan } \\
\text { potensi pemasaran yang } \\
\text { telah dilakukan (S1, O1) }\end{array}$ & $\begin{array}{l}\text { Memanfaatkan peluang } \\
\text { pemasaran ikan teri kering } \\
\text { yang dilakukan pada pasar } \\
\text { lokal dan pasar luar daerah } \\
\text { dengan mengatasi proses } \\
\text { pengeringan yang masih } \\
\text { bersifat tradisional (W2, O1) }\end{array}$ \\
\hline $\begin{array}{l}\text { Ancaman (Threats-T) } \\
\text { Belum adanya kerjasama } \\
\text { dengan pemerintah untuk } \\
\text { pemasaran produk ikan teri } \\
\text { kering (T1) } \\
\text { Fluktuasi harga penjualan (T2) } \\
\text { Persediaan bahan baku } \\
\text { berdasarkan musim (T3) } \\
\text { Belum memiliki kemasan untuk } \\
\text { produk (T4) }\end{array}$ & $\begin{array}{l}\text { Memanfaatkan komunikasi } \\
\text { yang baik antara konsumen } \\
\text { dan produsen untuk } \\
\text { mengatasi persediaan } \\
\text { bahan baku yang } \\
\text { berdasarkan musim (S1, } \\
\text { T3) }\end{array}$ & $\begin{array}{l}\text { Melakukan inovasi terhadap } \\
\text { proses pengeringan ikan teri } \\
\text { kering yang masih bersifat } \\
\text { tradisional untuk mengatasi } \\
\text { persediaan bahan baku yang } \\
\text { berdasrkan musim (W2, T3) }\end{array}$ \\
\hline
\end{tabular}




\section{PENUTUP}

\section{Simpulan}

Secara umum, alur pemasaran yang dilakukan nelayan dengan memasarkan ikan teri kering secara langsung ke pedagang pengumpul (tengkulak), kemudian pedagang pengumpul tersebut memasarkan ikan teri kering tersebut ke tingkat pedagang kecil hingga sampai pada konsumen akhir. Dalam sistem pemasaran ini, pedagang pengumpul juga mengirim produknya ke luar daerah.

Ada hambatan pada aspek teknologi komunikasi seperti terbatasnya fasilitas komunikasi atau fasilitas komunikasi yang kurang memadai untuk melakukan promosi dengan penggunaan teknologi komunikasi. Fasilitas komunikasi yang digunakan untuk memasarkan ikan teri kering, adalah menggunakan telepon seluler (handphone).

Strategi pemasaran yang dapat dilakukan oleh nelayan ikan teri kering untuk promosi produk ikan teri kering adalah dengan promosi langsung yakni penjualan langsung secara tatap muka dan melalui mulut ke mulut (word of mouth), juga penjualan di tempat (point of purchase communcation) dan penggunaan teknologi (media televisi lokal, radio, Facebook, Twitter dan lain-lain).

Pemasaran dilakukan pada pasar lokal dan pasar di luar daerah. Faktor ini menjadi salah satu peluang yang sangat penting dalam komunikasi pemasaran ikan teri kering di Kabupaten Maluku Tenggara. Hal ini juga didukung oleh faktor-faktor peluang lainnya, yang merupakan peluang cukup penting untuk diperhatikan.

\section{Saran}

Diharapkan bagi pedagang ikan teri kering supaya dapat mengatasi masalah yang dihadapi di pasar terkait dengan jumlah pesanan yaitu dengan menerapkan strategi komunikasi pemasaran agar pedagang ikan teri kering selalu dapat melayani dan memenuhi jumlah permintaan konsumen terhadap ikan teri kering dan dapat melakukan berbagai macam promosi untuk meningkatkan pemasaran ikan teri kering di Kabupaten Maluku Tenggara.

\section{DAFTAR PUSTAKA}

David, F.R. (2011) Strategic ManagementManajemen Strategis: Konsep. 12th edition. Jakarta, Salemba Empat.

Dwiastuti, I. (2008) Analisis Manajemen Strategi Industri Energi Alternatif: Studi Kasus Biofuel. Jurnal Ekonomi dan Pembangunan. 16 (1), 21-33.

Hubeis, M. \& Najib, M. (2008) Manajemen Strategik dalam Pengembangan Daya Saing Organisasi. Jakarta, Elex Media Komputindo.

Keller, K.L. \& Kotler, P. (2008) Manajemen Pemasaran. 12th edition. Jakarta, Erlangga.

Kotler, P. \& Amstrong, G. (2008) Prinsip-Prinsip Pemasaran. 12th edition. Jakarta, Erlangga.

Pearce, J.A. \& Robinson, R.B. (2008) Manajemen Strategis: Formulasi, Implementasi, dan Pengendalian. Jakarta, Salemba Empat.

Purwanto, I. (2008) Manajemen Strategi. Bandung, Yrama Widya.

Rangkuti, F. (2004) Analisis SWOT Teknik Membedah Kasus Bisnis: Reorientasi Konsep Perencanaan Strategis Untuk Mencapai Abad 21. Jakarta, Gramedia Pustaka Utama.

Sedjati, S. (2006) PENGARUH KONSENTRASI KHITOSAN TERHADAP MUTU IKAN TERI (Stolephorus heterolobus) ASIN KERING SELAMA PENYIMPANAN SUHU KAMAR. [Online]. Universitas Diponegoro. Available from: http://eprints.undip.ac.id/15874/.

Shimp, T.A. (2014) Komunikasi Pemasaran Terpadu dalam Periklanan dan Promosi. 8th edition. Jakarta, Salemba Empat.

Susianawati, R. (2006) KAJIAN PENERAPAN GMP DAN SSOP PADA PRODUK IKAN ASIN KERING DALAM UPAYA PENINGKATAN KEAMANAN PANGAN DI KABUPATEN KENDAL. Universitas Diponegoro. 